\title{
RELIGIUS TOURISM : BLESS FOR EVERYONE, NOW AND THEN IN INDONESIAN ECONOMICS VALUE
}

\author{
Miya Dewi Suprihandari \\ Accounting Study Program, Mahardhika High School of Economic Surabaya, East Java, Indonesia \\ Parwita Setya Wardhani \\ Management Study Program, Mahardhika High School of Economic Surabaya, East Java, Indonesia \\ Iman Supriadi \\ Accounting Study Program, Mahardhika High School of Economic Surabaya, East Java, Indonesia
}

\begin{abstract}
Religion as the most important foundation of human life is also a unifying difference between humans. Between people, they are connected when some of them need some things that are not owned by some other, whatever their religion. In Indonesia, especially in areas known as the origin of several deceased religious leaders, now it has turned into a spot that is visited by many followers or groups of people of different faiths to get information as educational material for them. These conditions make the economic conditions of the area begin to change, where the surrounding community prepares everything that is expected to be able to support the changing situation and conditions. Religious tourism spot has become one of the phenomena of the emergence of economic changes in the surrounding community to grow to be more positive than the previous condition. Religious tourism is a turning point in the growth of the religious value of the community and the economic value of the surrounding community and migrant communities in the area, even regional income. To support this condition, it would be wise for the local government at the location to provide support in the form of improved suggestions and supporting infrastructure for the smooth and development of the economic conditions of the people in particular, and for local governments in general.
\end{abstract}

Keywords: Religious Tourism, Economic Value, Blessing

\section{INTRODUCTION}

Religion is the most important guide of a human's life. Religion is also a tool or means to connect with other human beings in their daily activities and unifying them. Among adherents of that religion will be interconnected when one or several of them need something that is not owned but owned by followers of other religions. This happens a lot in almost all over the world, including in Indonesia.

Many religious leaders or leaders in the world have not a small number of followers, although some are not native residents of a region or country where they last lived until they were buried (Ebadi, Mehdi, 2015). Like the Catholic religious leaders in the Vatican, some of them are not native Vatican citizens, but when they die, they are buried in the Vatican city. Likewise in Indonesia, some religious leaders or leaders 
in an area in Indonesia are not native residents of the place or region (Ebadi, Mehdi, 2015). However, when they died, they were buried where they had lived and spent most of their lives in the area.

A burial site for leaders or religious leaders, in general, will be a place that will be visited by many followers at certain moments. Followers or people who believe in and respect and believe in the knowledge that has been delivered by religious leaders or leaders most of them strongly believe in or believe in the existence of a sermon or blessing given by God Almighty or Allah SWT through these chosen people, even though they are gone (Taufiqurokhman, 2017). Aside from the burial place of the leader or religious leader, other places that become the destination of followers or people who make the pilgrimage are places that often become a place of stopover or a place where the leaders or religious leaders perform some religious rituals. In Indonesia, many temples from Hindu and Buddhist religions have also become places of interest for Hindus and Buddhists to make pilgrimages or perform religious rituals such as those practiced by religious leaders they believed in ancient times. Important and historic places according to the religion they believe are believed to also have and give blessings from God Almighty through knowledge and beliefs conveyed by the religious leaders (Menchik, J, 2014).

At present, many grave locations of religious leaders or leaders in the world and in Indonesia have changed their function to become tourist attractions (Ebadi, Mehdi, 2015). The conditions and situations are very contrary to the conditions and situations in the past. In ancient times, the location of the tomb of religious leaders was a closed place and was not allowed to be opened to the public. Some of them have even been opened to be visited by the general public, without exception (Menchik, J, 2014).

The condition of the location of some of the tombs of religious leaders or leaders who are open to the public has changed the way of the current community. These conditions and situations make people more open to many new cultures and insights, although they continue to uphold their indigenous customs and culture without changing anything. Because ancestral inheritance is something that must be maintained at all times, whatever happens. That way makes the next generation will better understand and understand and increasingly respect the generation before them better.

\section{LITERATURE REVIEW}

\section{Tourism}

Tourism is an activity that has been carried out by humans since the beginning of human civilization. This is done by humans to look around the circumstances that they think can eliminate a little boredom that they might feel. These activities they do alone or together with family, friends or closest colleagues. In addition to visiting places that are located close to where they live, they also visit places that are located some distance away, so they have to stay for some time at their destination.

At present, the tourism activities carried out by the community have varied widely, depending on the objectives and participants. In general, they will travel in groups, led and arranged by a coordinator who organizes tourism activities, from the beginning of the departure to the destination, until they return home. For heterogeneous public groups (outside the subject of religion), tourism activities aim to find out and get to know the destination of the destination, and eliminate boredom due to the daily activities that they have lived for some time. As for certain groups of people, they will visit certain locations related to their spiritual goals, it aims to further enhance the spiritual value of the beliefs they believe in and increase their respect for the religious leaders they believe in and the truth they have conveyed to their followers .

Religious Tourism 
For the people of Indonesia, the term religious tourism is an activity associated with visiting places that according to their beliefs are places that must be respected, guarded their holiness forever and are expected to add value and their belief in the religion they believe in. These places can be in the form of caves, mosques, or resting places for religious leaders who believe in the truth of the knowledge that has been conveyed. They generally leave together in groups, sometimes for several days. By undergoing these religious tourism activities, they believe that God Almighty or Allah SWT will bestow blessings on their life steps and add value to their belief in His Oneness.

Religious tourism is a process of activity that has actually been carried out by many people since time immemorial. In Indonesia, such activities used to be carried out by certain groups of people in order to pay tribute to the religious leaders they believed in, especially Muslims. Pilgrimage is another name for religious tourism which is now more widely known by the public. And now, religious tourism has turned into an activity that becomes a habit for a group of people, at certain moments which they consider to be a blessing if carried out (Galzacorta, Marina Abad and Omil, Basagaitz Guereno, 2016).

\section{Blessing}

The biggest thing that is generally expected by people who carry out religious tourism activities is getting blessings from Allah SWT or God Almighty for their lives. Blessing is an infinite value on something that is obtained by humans from Allah SWT or God Almighty. This is considered as very valuable in the life of every human being. Blessing is also wanted by every human being from the natural world around where they live for ever.

The form of blessing is not only in the form of wealth, health and safety, as well as other things in life, for example welfare, prosperity, ease and fluency in every activity, business, work, etc., which they do in life. These things are the dreams of all human beings in the world who believe in them. The results or toil or income obtained when someone finishes doing a work process, and is as useful as it should be, is also considered to be a blessing for the blessings of a human being and his family. Knowledge that is useful for many other humans is also considered a knowledge that contains blessings, and vice versa.

\section{METHODS}

Descriptive qualitative research methods used by the author to convey data obtained based on facts in the field and the phenomenon of the development of religious tourism activities in Indonesia which is increasing in frequency, especially those carried out by Muslims.

\section{RESULTS}

Tables and pictures are placed in the middle of the page. The title of the table is written above the table, while the title of the picture below the picture, both with Times New Roman 12 pt. Letters in the table, may use Times New Roman 10pt or 11pt, one space. Tables are described, with horizontal

\section{DISCUSSION}

\section{Indonesian Geographical Position}


Indonesia is one of the countries in the world that has a strategic position in the world. Being between two continents and two oceans makes Indonesia a haven for many ships from foreign countries in many of its seaports. As a place to stop many foreign sea vehicles became a famous port and agricultural country at the time. This makes the Archipelago (Indonesia) as the target of many foreign countries who want Indonesia more than just a haven when they go to other regions or countries around Indonesia.

Besides being between two continents, Indonesia is also around the equator, making Indonesia one of the largest agrarian countries. Indonesia is not only an agrarian country, Indonesia is also known as an archipelago with abundant marine resources, because the area of its waters is about two times larger than the size of the land owned and has a temperature that tends to be warm. The abundant natural wealth in the sea and land makes the Indonesian nation as a country that is much targeted by many foreign traders. These traders will usually spend more time stopping, even living in Indonesia.

Foreign traders who often stop or deliberately stop and spend some time to stay in Indonesia in general have set a goal to open cooperation with local Indonesian traders or farmers. Those who first stopped by to continue their trading objectives to other countries, in general, would return to stay for a while in Indonesia. This they do with the aim of obtaining information about high-value agricultural products in their countries or other countries that had previously been their purpose for trading. And when the information is obtained, in the next opportunity they will certainly come back to buy Indonesian agricultural products, even some of them intend to live in Indonesia.

\section{Cultural Assimilation Heritage}

Based on history, many traders who stopped at many ports in Indonesia in ancient times, generally came from South Asia, namely India (Gujarat). Some of the others also came from Europe and China. They generally look for spices that they don't partly get from their country's agricultural produce, or because Indonesian spices are of better quality than spices in their own country. In addition to trading activities and getting the desired spices, the traders can be sure to look for new friends or trade relations with farmers and their local partner traders.

During carrying out trading activities and establishing trade cooperation or exchanging merchandise with local Indonesian farmers and traders, these foreign traders will automatically begin to adapt in many ways. This adaptation or assimilation process is an effort that must be carried out by migrant traders if they want to get ease in their trading activities. One way to assimilate is to learn the customs of the area where they stopped. In fact, it is not only the migrant traders who carry out the assimilation process, the local residents and local merchant partners also do the same thing, so they are able to communicate well with one another (Shinde, Kiran A and Rizello, Katia, 2014).

The assimilation process that occurs between local residents and migrant traders, does not only occur in one thing. One of the things that happens in this assimilation process is the process of exchanging language learning to communicate well with one another. In addition to exchanging language learning in daily conversation activities, most of them also introduce new religions to the communities where they stop and stay temporarily. The introduction of this new religion is generally carried out by migrant traders from the Gujarat and Middle East regions (Shinde, Kiran A and Rizello, Katia, 2014).

When some foreign traders who finally settled in Indonesia began to make their choices to become residents and build families with local residents, that's when the new religion and culture as a result of assimilation began to form. In addition to foreign traders, there are also some Islamic leaders who deliberately came to Indonesia (Nusantara, as Indonesia was then) to preach. In the end, Islam was also 
adopted by community leaders, even some members of the aristocratic family eventually became leaders of Islam. This is not only happening in Java, but also in Sumatra, Kalimantan and West Nusa Tenggara (Nashuddin, 2016).

This condition eventually led to the people at that time increasingly believing in the religion of Islam, because people who they considered to be leaders and who could be trusted also embraced the same religion. So, when some of the leaders and religious leaders who they respect die, it is certain that their followers as well as the people will continue to pay their respects by always visiting his grave and sending endless prayers to them in that place, besides always sending and visiting the graves of their closest relatives also (Nashuddin, 2016). This has finally become a tradition that has always been practiced by many Muslims in Indonesia to date, which is referred to as Religious Tourism activities (Galzacorta, Marina Abad and Omil, Basagaitz Guereno, 2016).

The Religious Tourism Activity, eventually becomes an activity that is able to generate economic activity in the area around the destination location, as well as the community that conducts religious tourism activities. For business people, business opportunities as a coordinator of travel service providers in groups are one of them. So that people doing religious tourism do not need to feel difficult to prepare a vehicle or location to stay, even including consumption needs during the activity, until returning to their respective homes. The condition was finally able to change religious tourism activities into a fun and appropriate activity to be made a permanent agenda in their social and religious activities.

One positive result of the increasing frequency of religious tourism activities, currently has been a lot of growing activities providing transportation services supporting religious tourism activities. Providers of a variety of transportation services will generally provide transportation facilities with capacities in accordance with the requirements requested by the user. The transportation facility provider is currently trying to compete by providing facilities that increasingly spoil the user's desires, for example vehicles that are increasingly exclusive and comfortable. This makes the transportation sector also experience improvements in terms of income, as well as the needs of the human resource sector as a support for the transportation sector also increased (Cerutti, Stefania and Piva, Elisa, 2015).

The food service (catering) service sector that is around the abode of religious tourism activities is currently believed to also experience an increase in income as the frequency of religious tourism activities increases (Cerutti, Stefania and Piva, Elisa, 2015). This side is also able to have an impact on increasing the income of nine-basic food sellers and several other sellers of supporting needs. The absorption of human resources has also increased in this sector. The variety of desires or needs demanded by religious tourism practitioners, has increased the range of catering and snack food service providers.

Business opportunities for people in locations around religious tourism are no less great. At present, all fields around the location of religious tourism are experiencing a significant change. Growth or development is almost the same as in the community around the place of residence of visitors to religious attractions, ranging from the transportation sector, culinary, handicraft local products, lodging facilities, and other supporting facilities. It can be said, community activities around the area of religious tourism currently almost last for more than 12 hours a day.

The culinary and craft sector seems to have become a means to introduce the local wealth owned by the religious tourism area. This causes the local wealth exploration process of an area to be more actively carried out. Even the anniversary of the death of the religious leader has been made an annual agenda and is always reported to the wider community to outside the region, even through social media. So that we can be sure the number of visitors will experience a tremendous increase, even not a few tourists from other countries come for the tour agenda. 
With the development of these activities into an agenda or a fixed schedule of a religious tourism location, it is certain that the local government also receives a pretty good increase in income. Because, it can be ascertained that the wheels of the economy of the community and the area around the location of religious tourism are in a positive condition. The velocity of money in society is also dynamic. There is a lot of money spent by many tourists who come, whether from the surrounding area, other cities outside the island, even from outside the country (Suradin, Muhammad, 2018).

The activity of spending money by tourists from outside the country makes the velocity of money in the community occur not only in the destination area, but has already begun when they arrived at the airport. When they are interested in stopping by and staying a few days afterwards, we can be sure that their spending activities in our currency will increase. The more attractive the tourist sites they visit, automatically, their desire to return or invite family or friends will increase (Suradin, Muhammad, 2018). The situation eventually becomes an infinite blessing that Allah SWT has given to the surrounding community, local government and the central government..

\section{CONCLUSION}

The legacy of religious leaders in the past gives an infinite value of blessing to the community around his final rest. Not only a variety of beliefs, but also a variety of cultures, one of which is religious tourism activities. Religious tourism activities whose initial purpose is only a form of activity to visit the last resting place of religious leaders in the past, which can be done individually or in groups, as a form of highest respect while still remembering them and praying for them. One form of blessing in the form of prosperity and improvement of the economic conditions of the surrounding community is one of an infinite legacy (Anwar, Muhammad Fahrizal; Djamhur Hamid and Topowijono, 2017).

Local wealth owned by the destination of religious tourism locations is also beginning to be known by people outside the region, even outside the country. This is expected to be a trigger for the community around the location, the regional government in particular and the central government in general, to further improve the quality and quantity of facilities and infrastructure as a support (Anwar, Muhammad Fahrizal; Djamhur Hamid and Topowijono, 2017). Because the facilities and infrastructure are quality and well maintained, it will greatly help improve economic improvement at all levels. These include improving the quality of human resources in religious tourism destinations with communication skills in a variety of foreign languages, as well as competent knowledge capabilities about religious tourism locations and religious leaders who are buried at these locations (Chitranshi, Jaya.Dr, 2014).

Assistance by local and central government is expected to be able to improve the quality of all layers that play a role in the development and maintenance of religious tourism destination locations. It is also hoped that this will help maintain the boundaries of exploration for local wealth, so that it does not exceed established limits. In terms of local culture, the assistance activities are expected to be able to prevent the possibility of contamination by foreign cultures that are considered not suitable to be absorbed, especially for young people in the tourist sites. To that end, the government can involve the younger generation in an effort to improve, develop and strengthen the local cultural values that have been inherited, so that the nation will maintain its noble values even though economic conditions are beginning to improve in several business sectors in this global era (Shinde), Kiran A and Rizello, Katia, 2014).

In addition, in order to support the development of economic improvement in the environment around religious tourism sites, it would be better for local governments to provide serious support for the 
human resource sector (Chitranshi, Jaya.Dr, 2014). Local governments can provide assistance in the form of training for the development of community creativity around the tourist sites (Sharma, Veena, 2013). It is expected to be able to increase the productivity and creativity of human resources in the environment, so that it can support the needs and requests for souvenirs as a characteristic of the areas visited, or other products (Raj, Razaq. Dr. and Bozonelos, Dino, 2015). Routine assistance after training is also an important thing that should be done by local and central government if needed by the community. It would even be better for local and central governments to help develop markets for existing products, so that these products are increasingly recognized by the wider market environment, both nationally or even reaching international markets, being able to compete with products from competitors (Raj, Razaq. Dr. and Bozonelos, Dino, 2015).

In expanding market activities, it would be better if the government also provides training as a form of support to the creative economy businesses around the religious tourism location. Businesses are also given training related to product promotion activities, supporting facilities and infrastructure in the tourist location (Sharma, Veena, 2013). The training activities need to be carried out because of the global era asking businesses to respond more quickly to market needs, so that the slightest opportunity available will not be missed (Okonkwo, Emeka, 2015). So that distance is no longer an obstacle for people in the area to be able to develop and be known by people from other cities or provinces, even other countries (Olsen, Daniel H, 2013).

As the community becomes increasingly familiar with the region outside the region, additional revenue for the local government and central government can occur. This has become a positive condition for changes in the level of income of local creative economy actors, being able to compete with national and international markets (Olsen, Daniel H, 2013). National and international markets will increasingly take into account the competitiveness of creative economic actors from the regions. Because the characteristics of people and regions that cannot be defeated and changed by global changes in many sectors (Okonkwo, Emeka, 2015).

\section{ACKNOWLEDGEMENT}

The author would like to thank the support given by the second and third authors as well as the previous writers in the bibliography, as well as the community of religious tourism practitioners who have supported the economic development around the sacred tourism area in Indonesia.

\section{REFERENCES}

Anwar, Muhammad Fahrizal; Djamhur Hamid and Topowijono, 2017, Impact Analysis of Sunan Maulana Malik Ibrahim's Tomb Religious Tourism Development in the Social and Economic Life of Surrounding Communities (Study in Gapurosukolilo Village, Gresik Regency), Journal of Business Administration (JAB), Vol. 14

Cerutti, Stefania and Piva, Elisa, 2015, Religous Tourism and Event Management: An Opportunity for Local Tourism Development, International Journal of Tourism and Pilgrimage, Vol. 3

Chitranshi, Jaya.Dr, 2014, Empowering Organization, A Journal of Management Sciences, Vol. 4

Ebadi, Mehdi, 2015, Forms of Pilgrimage at the Shrine of khaled Nabi, Northwestern Iran, International Journal of Religious Tourism adn Pilgrimage, Vol. 3 
Galzacorta, Marina Abad and Omil, Basagaitz Guereno, 2016, Pilgrimage As Tourism Experience: The Case Of The Ignation Way, International Journal of Religious Tourism and Pilgrimage, Vol. 4

Menchik, J, 2014, Productive Intolerance : Godly Nasionalism in Indonesia, Comparative Studies in Society and History Journal.

Nashuddin, 2016, The Management of Muslim Spiritual Tourism In Lombok, Indonesia : Opportunities and Challenges, Journal of Indonesian Islam, Vol.10.

Okonkwo, Emeka, 2015, Religious Activities and Their Tourism Potential in Sukur Kingdom, Nigeria, International Journal of Religious Tourism adn Pilgrimage, Vol. 3

Olsen, Daniel H, 2013, A Scalar Comparison of Motivation and Expectations of Experience within The Religious Toursm Market, International Journal of Religious Tourism and Pilgrimage, Vol. 1

Raj, Razaq. Dr and Bozonelos, Dino, 2015, Pilgrimage Experience and Consumption of Travel to the City of Makkah for Hajj Ritual, International Journal of Religious Tourism and Pilgrimage, Vol. 3

Sharma, Veena, 2013, Faith Tourism: for a Healthy Environment and More Sensitive World, International Journal of Religious Tourism adn Pilgrimage, Vol. 1

Shinde, Kiran A and Rizello, Katia, 2014, A Cross-cultural Comparison of Weekend-trips in Religious Tourism: Insights From Two Cultures, Two Countries (India and Italy), International Journal of Religious Tourism and Pilgrimage, Vol. 2

Suradin, Muhammad, 2018, Halal Tourism Promotion In Indonesia : An Analysis On Official Destination Website, Journal of Indonesian Tourism and Development Studies, Vol.6.

Taufiqurokhman, 2017, The Role Of Ulama and Muslims in Strenghthening National Union of The Republic of Indonesia, CosmoGov Journal. 